\title{
コンクリートの圧縮試験における \\ 供試体上端面の圧力分布と縦ひずみに及ぼす影響 \\ COMPRESSIVE PRESSURE DISTRIBUTION ON END FACE OF CONCRETE SPECIMENS AND ITS INFLUENCE ON MEASURED STRAIN DISTRIBUTION
}

\author{
藤木 諒 将*1, 畑中 重 ${ }^{*}{ }^{* 2}$, 三島直生 ${ }^{* 3}$ \\ Ryosuke FUJIKI, Shigemitsu HATANAKA and Naoki MISHIMA
}

\begin{abstract}
Uniaxial loading pressure distribution acturely applied on end surface of specimens were measured by using the pressure sheets. Also, its influence on the measured values of compressive strength and longitudinal strains were investigated.

1) The average value of the strain and Young's modulus were similar irrespective of the end surface treatment method.

2) By using average value of the two opposite side strains, influence of step on the upper end face on Young's modulus was reduced.

3) In the FEM analysis using the measured pressure distribution, the influence of the pressure distribution on the upper end face of the specimen was largely reproduced, in the strain distribution.
\end{abstract}

Keywords : Cement concrete, Pressure sheets, Pressure distribution, Strain distribution, Young's modulus, End surface of a specimen コンクリート，圧力測定フィルム，圧力分布，ひずみ分布，静弹性係数，供試体端面

\section{1. 序論}

コンクリートの圧縮強度試験時に用いられる供試体の上面の仕上 げ方法として JIS A 1132 では，キャッピング，研磨およびアンボン ドキャッピングが規定されている。アンボンドキャッピングについ ては, 辻本ら 1),2)により詳細な研究が行われている。キャッピング用 の材料は，コンクリートによく付着し，かつコンクリートに悪影響 を与えないものとされ, 一般的にセメントペースト, 硫黄, 硬質石 こうなどが用いられる。

このような方法により仕上げられたコンクリート供試体の端面の 平滑さは, 圧縮強度試験の結果を左右する重要な要因であり, コン クリートの強度レベルによっては, 端面の平滑さにより見かけの圧 縮強度（測定值）が大きく変化する可能性がある ${ }^{3), 4}$ 。例えば, 供試 体端部の凹凸の影響を調查した実験によれば, $0.2 \mathrm{~mm}$ 程度の凸部を 有する場合, 圧縮強度が 10\%程度低下寸ることが報告されている5)。 また, たとえ見かけの圧縮強度が変わらなくても, 載荷初期の応力 状態により供試体内部の応力分布が異なるため, 供試体のひずみ分
布も異なると考えられる。従って, 圧縮試験の際, 載荷面の忘力分 布の均一性を把握することも重要といえる。なお，最近では鈴木ら 6),7)により，供試体の平面度に関する詳細な検討も行われている。

圧力測定フィルムを用いた載荷面の圧力測定に関して, 文献 8),9) においては圧力測定フィルムの取扱いおよび保存期間等が及ぼす測 定值への影響の検討がなされている。また，端面処理方法による圧 縮強度への影響および端面処理の強度レベルによる適用範囲の検討 10)-13) や，高強度コンクリートの h/d が円周方向のひずみおよび載荷

Table 1 Factors and testing levels

\begin{tabular}{c|c|c}
\hline Exp. No. & factors & testing levels \\
\hline \hline Exp. 1 & $\begin{array}{c}\text { end surface of } \\
\text { specimen treatment }\end{array}$ & $\begin{array}{c}\text { cement paste capping } \\
\text { ground ends } \\
\text { sulfur capping } \\
\text { unbonded capping }\end{array}$ \\
\hline Exp. 2 & $\begin{array}{c}\text { magunitude of step of } \\
\text { the upper end face } \\
\text { (Fig. 2) }\end{array}$ & $\begin{array}{l}0.1 \mathrm{~mm} \\
0.2 \mathrm{~mm}\end{array}$ \\
\hline
\end{tabular}

Table 2 Mix proportion and fresh properties of concrete

\begin{tabular}{|c|c|c|c|c|c|c|c|c|c|c|c|}
\hline \multirow{2}{*}{$\begin{array}{c}\mathrm{F} \\
\left(\mathrm{N} / \mathrm{mm}^{2}\right) \\
\end{array}$} & \multirow{2}{*}{$\begin{array}{l}\mathrm{SL} \\
(\mathrm{cm})\end{array}$} & \multirow{2}{*}{$\begin{array}{l}\text { Air } \\
(\%)\end{array}$} & \multirow{2}{*}{$\begin{array}{l}\text { W/C } \\
(\%)\end{array}$} & \multirow{2}{*}{$\begin{array}{l}\text { s/a } \\
(\%)\end{array}$} & \multicolumn{4}{|c|}{ unit we ight $\left(\mathrm{kg} / \mathrm{m}^{3}\right)$} & \multicolumn{3}{|c|}{ fresh properties } \\
\hline & & & & & W & $c$ & $s$ & $G$ & $\mathrm{~T}_{\mathrm{c}}\left({ }^{\circ} \mathrm{C}\right)$ & $\mathrm{SL}(\mathrm{cm})$ & Air $(\%)$ \\
\hline "30 & 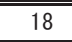 & 4 & (262.6 & 年4. & 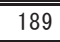 & $\begin{array}{l}302 \\
\end{array}$ & " & (844 & 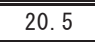 & $\begin{array}{l}17.5 \\
\end{array}$ & "1.8 \\
\hline
\end{tabular}

[Note] F: Target compressive strength, SL: Slump value, Air: Air content, W/C: Water cement ratio by weight, s/a: Fine aggregate ratio by volume, Tc: Concrete temperature

*1 三重大学大学院工学研究科建築学専攻 大学院生

*2 三重大学大学院工学研究科建築学専攻 教授・工博

* 3 三重大学大学院工学研究科建築学専攻 准教授·博士 (工学)

Grad. Student, Div. of Arch., Graduate School of Eng., Mie Univ.

Prof., Div. of Arch., Graduate School of Eng., Mie Univ., Dr.Eng.

Assoc. Prof., Div. of Arch., Graduate School of Eng., Mie Univ., Dr.Eng. 


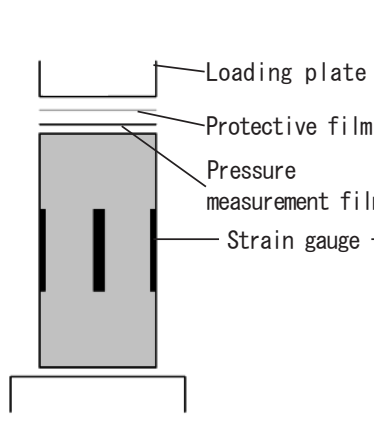

(a) sulfur capping cement paste capping ground ends

Fig. 1 Schematic view of specimens (Exp. 1)

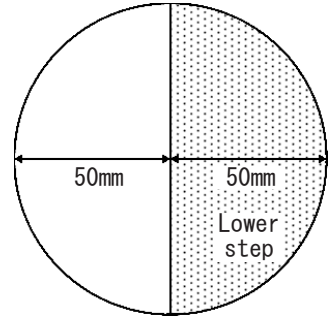

(a) top view

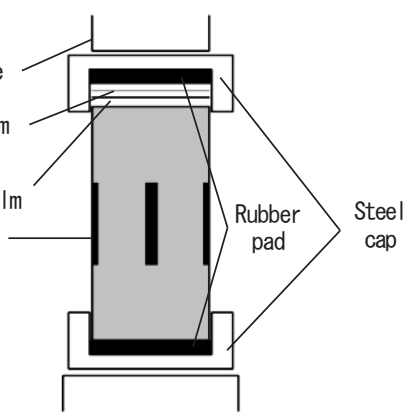

(b) unbonded capping

Fig. 2 Specimen with a step on the upper end face (Exp. 2)

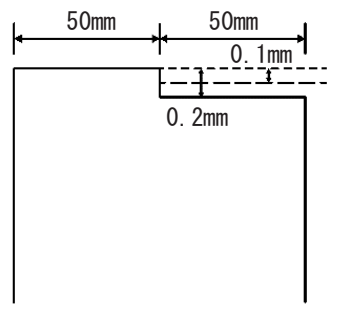

(b) side view

load color forming layer

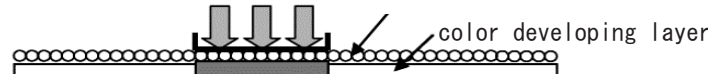
substrate

Fig. 3 Color development system of pressure measurement $\mathrm{fi} \mid \mathrm{m}^{4)}$

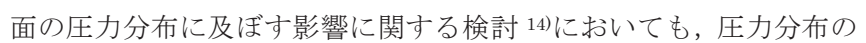
測定にあたって圧力測定フィルムが用いられた。

一方で，応力段階ごとに圧力分布を計測した例は少なく ${ }^{15)}$ ，載荷 途中の圧力分布が軸方向のひずみに及ぼす影響は明らかとなってい ない。本研究では, 普通強度レベルのコンクリートを対象とし, 端 面処理方法の違いが，載荷に伴う圧力分布の変化および軸方向ひず みに及ぼす影響について検討する。また, 実験で得られた各応力段 階の圧力分布を, 有限要素解析モデルに入力し, 縦ひずみ分布およ び応力ひずみ曲線に及ぼす圧力分布の影響について, 解析的に検討 する。すなわち本研究は，1）応力段階ごとの圧力分布の変遷，2）供 試体周囲の縦ひずみの分布状況および3）圧力分布を入力した FEM 解析に着目している。

なお，本論文は既報 16)を修正し，大幅に加筆したものである。

\section{2. 実験概要}

\section{1 実験方法と要因水準}

本実験では, 圧力測定フィルム 8),9)を用い, 端面処理方法の異なる 供試体上端面の応力分布を明らかにする。コンクリートの目標圧縮 強度は普通強度を想定して $30 \mathrm{~N} / \mathrm{mm}^{2}$ とし, 各応力段階の圧力分布

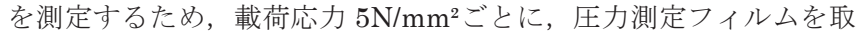
り替えた。圧縮強度試験は JIS A 1108 に準拠し, 載荷速度は規定に 則り毎秒 $0.6 \pm 0.4 \mathrm{~N} / \mathrm{mm}^{2}$ 以内とした。

Table 1 に実験の要因と水準を, Table 2 にコンクリートの調合と

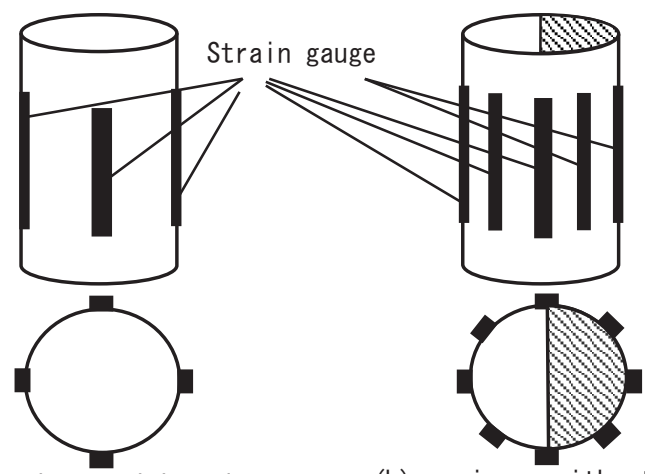

(a) Specimens with end surface treatment

(b) specimens with step

Fig. 4 Position of strain gauges

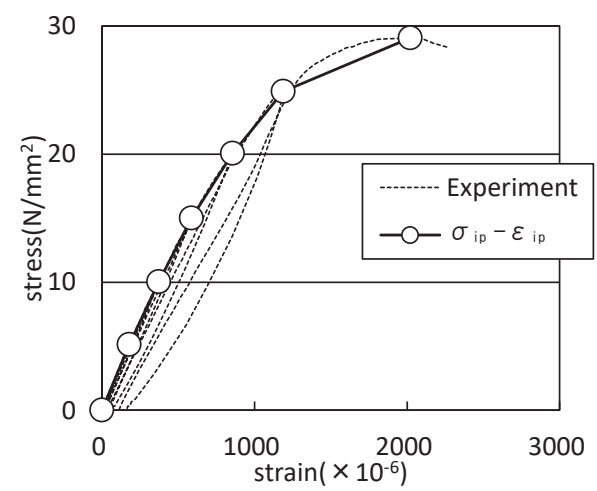

Fig. 5 Conceptual diagram of $\sigma_{i p}-\varepsilon_{i p}$ curve

フレッシュ性状を示す。供試体は, JIS A 1132 に準拠して作製した。 この際，設計空気量 $4.5 \%$ に対して実測空気量が $1.8 \%$ と少なくなっ ているが、この影響としては圧縮強度レベルが僅かに上昇する以外 には変形および破壊挙動に対しては大きな影響がないと考え、実験 はそのまま実施した。

実験は 2 シリーズ行い，実験 1 では，供試体載荷面の応力分布に 及ぼす供試体上端面（載荷面）の処理方法の影響を検討する。実験 2 では，JIS A 1132 に規定された載荷面の平面度の規定を超過し， 載荷時に極端な圧力集中が生じる状態を設定することとした。その ため，供試体上端面に人為的に段差を設け，この段差がひずみ分布 および圧力分布に及ぼす影響を検討する。実験 1 の供試体の概要図 を Fig. 1 に，実験 2 の供試体上端面の状態を Fig.2 に示す。

上端面に段差を設ける供試体は Fig.2 に示すように，上端面の半 分に対し,他方と比較して $0.1 \mathrm{~mm}$ または $0.2 \mathrm{~mm}$ 低くなるよう段差 を設ける。

\section{2 圧カ測定フィルムについて ${ }^{4)}$}

圧力測定フィルムには，低圧用から超高圧用の 4 種類の製品があ り，基層上に発色剂層と顕色剂層が塗布されている。Fig.3 に示すよ うに，上層である発色剂層のマイクロカプセルが圧力によって破壊 され，その中の発色剂が顕色剂に吸着すると化学反応で発色する。 発色剂のマイクロカプセルは, いろいろな大きさ・強度に調整され， 均一に塗布されており，圧力に応じた赤色の発色濃度が得られる。 また，圧力測定フィルムには，一枚に発色剂層と顕色剂層を塗布し たモノシートタイプ，発色剂層と顕色剂層が分かれたツーシートタ イプがあり，本研究では低圧用フィルムのツーシートタイプ（測定 


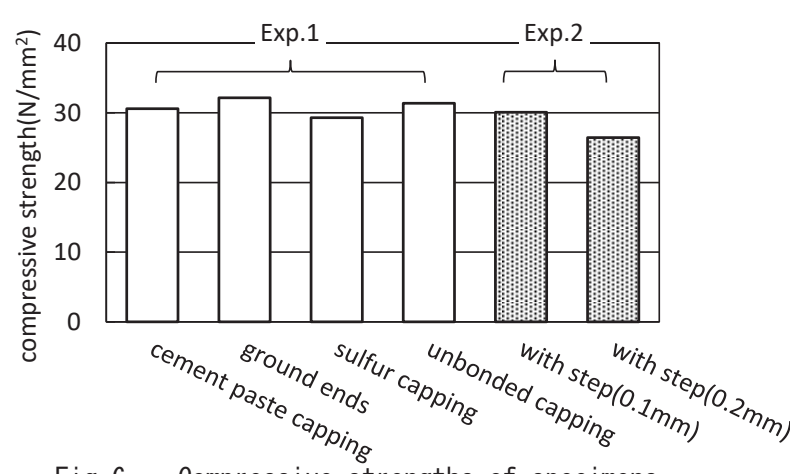

Fig. 6 Compressive strengths of specimens with various end surface treatment

範囲 2.5-10MPa), および中圧用フィルムのモノシートタイプ（測 定範囲 10-50MPa）を使用した。

\section{3 端面処理方法}

実験 1 では, 供試体の端面処理方法を, セメントペーストキャッ ピング, 研磨, 硫黄キャッピングおよびアンボンドキャッピングの 4 水準とした。この際, 各種端面処理に関して, セメントペースト キャッピングおよび研磨仕上げは上面のみ, 硫黄キャッピングは上 下端面ともに実施した。

実験 2 では, 供試体の上端面に設ける段差を $0.1 \mathrm{~mm}$ および $0.2 \mathrm{~mm}$ の 2 水準とした。なお, Fig.2 のような上端面に段差を設ける供試 体は, プラスチック製簡易型枠の底面に直径 $100 \mathrm{~mm}$ の半円状に切 った $\mathrm{OHP}$ シート（厚さ $0.1 \mathrm{~mm}$ ) を敷いて作製した。このため, 載 荷時底面（打込み時型枠上面）にはセメントペーストキャッピング を施した。

供試体は直径 $100 \mathrm{~mm}$ で一定とし, 各水準につき 2 本作製した。

\section{4 ひずみ分布および静弾性係数の測定方法}

圧縮強度試験時に, 応力段階 $5 \mathrm{~N} / \mathrm{mm}^{2}$ 毎に圧力測定フィルムによ り圧力分布を測定した。また, 並行して供試体の縦ひずみをゲージ 長 $60 \mathrm{~mm}$ のワイヤーストレインゲージを用いて測定した。

後掲の Fig.16 における応力ひずみ曲線は, Fig.5 の概念図に示す ように, 応力段階ごとの最大応力 $\sigma$ ip と対応するひずみ $\varepsilon$ ip $の$ 関係と してプロットした。この際, ひずみの值には, 貼付したひずみゲー ジによる值をそのまま用いており, 若干ではあるが, 繰返し載荷に よる残留ひずみの影響を含むことになる。

端面処理を施した供試体は, Fig.4(a)のように 4 本のひずみゲー ジで，上端面に段差を施した供試体は，Fig.4(b)のように 8 本のひ ずみゲージで縦ひずみを測定した。静弾性係数は JIS A 1149 に準 拠して算出した。ただし, 供試体の縦ひずみは, 先述した 4 本また は 8 本の縦ひずみの平均值を用いた。

\section{3. 実験結果および考察 \\ 3.1 圧縮強度の測定結果}

圧縮強度試験の結果を Fig.6 に示す。圧縮強度試験は JIS A 1108 に準拠し, 測定結果より算出した。同図より, 端面処理方法による 供試体の圧縮強度には, 明確な差は見られなかった。一方で, 供試 体の上部端面に段差を設けた実験 2 においては, 段差 $0.1 \mathrm{~mm}$ およ び各端面処理方法と比較して, 段差 $0.2 \mathrm{~mm}$ の圧縮強度が $4 \mathrm{~N} / \mathrm{mm}^{2}$ 程度低下寸る傾向が見られた。また, この際 2 本の供試体の圧縮強

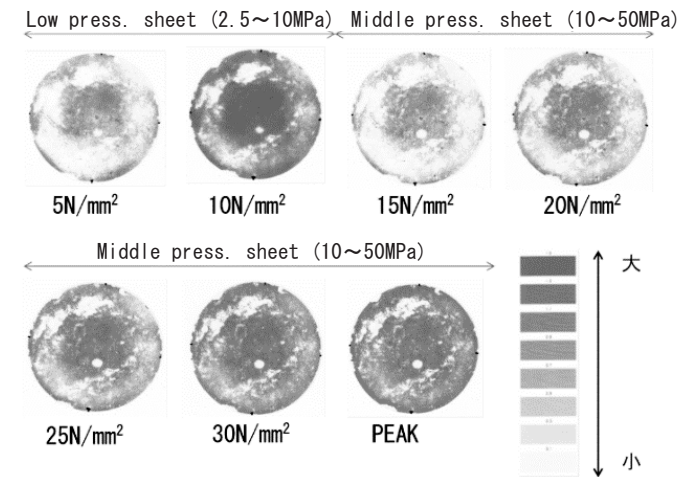

Fig. 7 Pressure distribution diagram of each stress stage (cement paste capping)

(a) Stress stage $5 \mathrm{~N} / \mathrm{mm}^{2}$
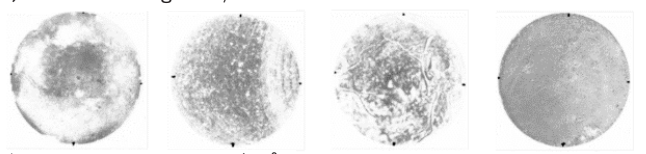

(b) Stress stage $30 \mathrm{~N} / \mathrm{mm}^{2}$
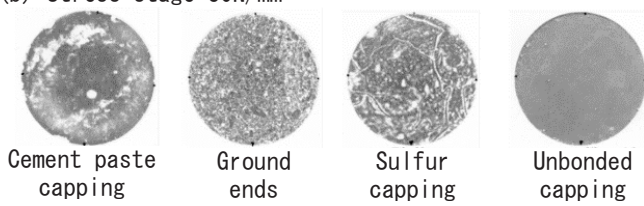

Fig. 8 Pressure distribution diagram of each end surface treatment

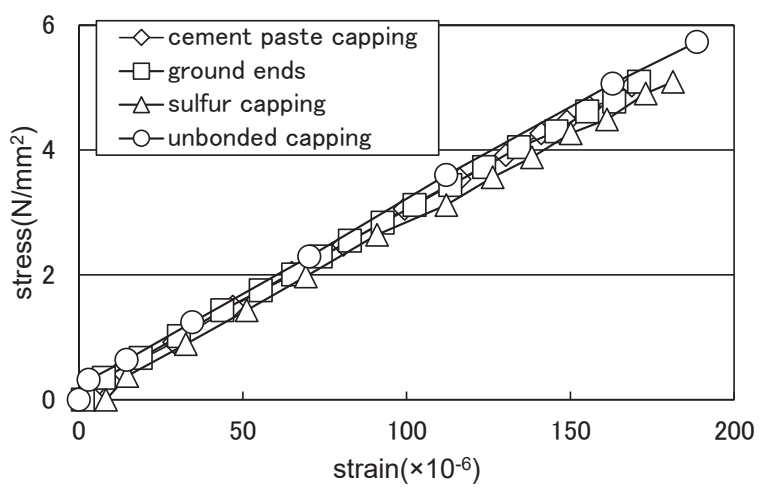

Fig. 9 Stress-strain curve at stress stage of about $5 \mathrm{~N} / \mathrm{mm}^{2}$ for each end surface treatment

度の差異は, 段差 $0.2 \mathrm{~mm} の 4.8 \%$ が最大であった。

以上の結果から，端面処理方法の違いが圧縮強度に及ぼす影響は ほぼ見られないが，上端面の段差が生じているような場合において は，段差が $0.2 \mathrm{~mm}$ 程度になると圧縮強度に対して影響を及ぼすと 考えられる。これは, 後述する供試体端面の圧力分布に起因寸る, 内部応力の集中によるものと考えられる。

\section{2 端面処理方法の違いによる検討（実験 1) \\ (1) 各応力段階における圧力分布}

Fig.7 に，セメントペーストキャッピングの各応力段階における 供試体端面の圧力分布を示す。同図より，供試体端部にかかる圧力 の大まかな分布は維持されたまま, 応力段階の進展に伴って発色濃 度が増大していることが確認できる（ただし, 応力が $10 \mathrm{~N} / \mathrm{mm}^{2}$ と $15 \mathrm{~N} / \mathrm{mm}^{2}$ の間で圧力測定フィルムが低圧用から中圧用に切り替え られている)。同様の傾向は, すべての供試体において確認された。 


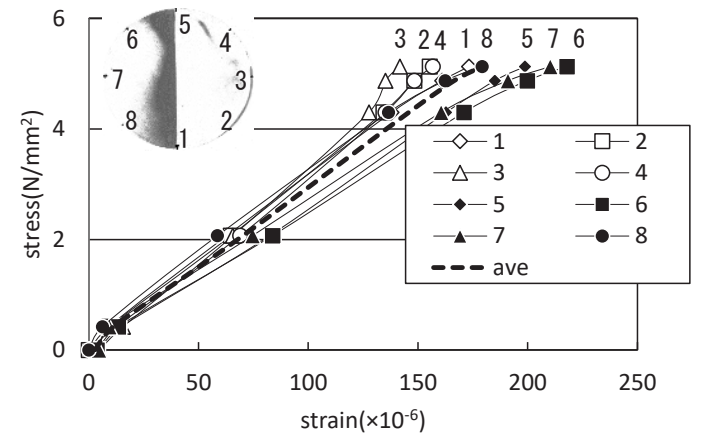

Fig. 10 Stress-strain curve and stress distribution diagram up to stress stage of $5 \mathrm{~N} / \mathrm{mm}^{2}$ of specimen with step $0.1 \mathrm{~mm}$

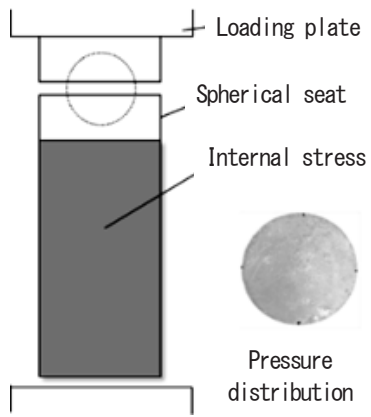

(a) end surface treatment (unbonded)

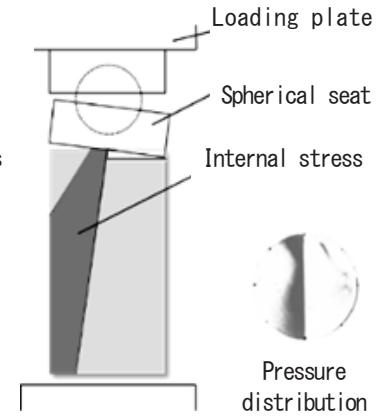

(b) with step
Fig. 11 Conceptual diagram of internal stress during compressive strength test

\section{（2）各端面処理方法による圧力分布とひずみの影響}

Fig.8 に, 応力段階 $5 \mathrm{~N} / \mathrm{mm}^{2}$ および $30 \mathrm{~N} / \mathrm{mm}^{2}$ のときの各端面処 理方法による圧力分布図を示す。

同図より, 応力段階 $5 \mathrm{~N} / \mathrm{mm}^{2}$ のときには, 各端面処理方法におい て, 端面内の圧力に偏りが見られる。例えば, 研磨した端面ではド リルの痕跡が顕れている。しかし, 応力段階 $30 \mathrm{~N} / \mathrm{mm}^{2}$ においては, すべての供試体において, 圧力分布図が比較的一様となっており, 端面内の圧力の偏りが小さいことが分かる。また, Fig.9 は載荷開 始から応力段階 $5 \mathrm{~N} / \mathrm{mm}^{2}$ までの応力ひずみ曲線（ひずみは 4 枚のゲ ージの平均值）を示したものであるが, 図によれば, 載荷時の圧力 分布が供試体の応力ひずみ関係に及ぼす影響はほとんどないといえ る。

\section{3 供試体の上端面に設けた段差の影響の検討（実験 2）}

Fig.10に, 段差 $0.1 \mathrm{~mm}$ の供試体について各ひずみゲージから得 られた応力段階 $5 \mathrm{~N} / \mathrm{mm}^{2}$ までの応力ひずみ曲線および圧力分布図を 示す。図によれば, ゲージ $5,6,7$ のひずみが大きく, ゲージ $2,3,4$ のひずみが小さい。しかし, 応力段階 $5 \mathrm{~N} / \mathrm{mm}^{2}$ の時点で, 圧力分布 図においてはゲージ 6, 7 の辺りに圧力がほとんどかかっていない ことから, 初期の応力段階においては上端面の圧力分布とひずみが 対応していないことが分かる。

この一つの原因として, Fig.11(b)に示すように, 球座が斜めとな り，上端面の応力が内部に垂直（Fig.11(a)はアンボンドキャッピン グの例）に伝わらず, 図中に示すような内部応力の流れが生じたこ とが考えられる。

上端面に $0.1 \mathrm{~mm}$ の段差を設けた供試体について, $10 \mathrm{~N} / \mathrm{mm}^{2}$ にお

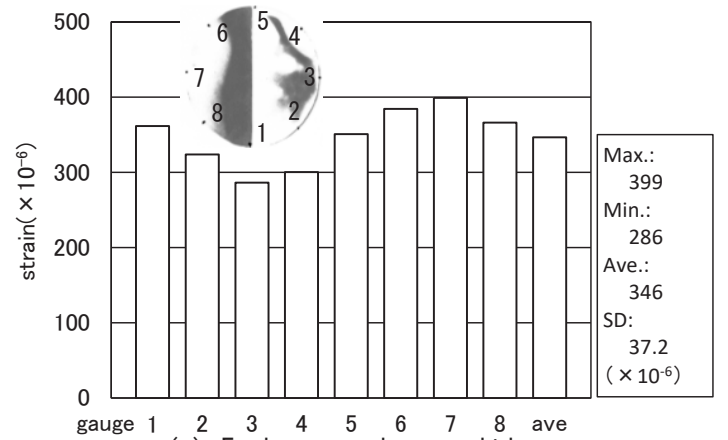

(a) Each measuring position

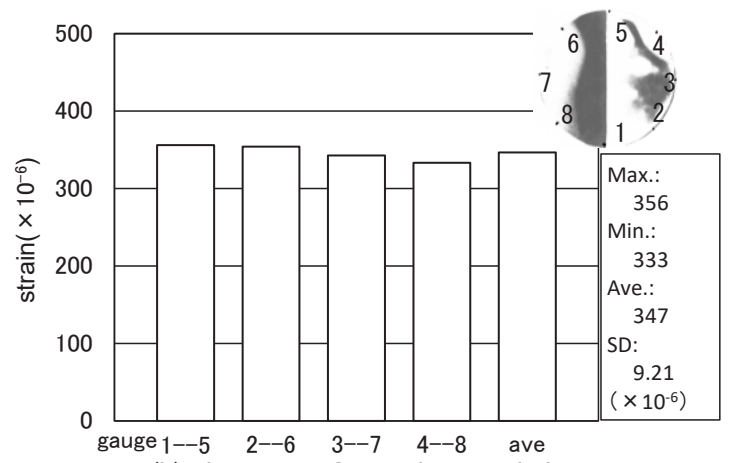

(b) Average of oppsite position

Fig. 12 Variation of Young's modulus (Step $0.1 \mathrm{~mm}$ )

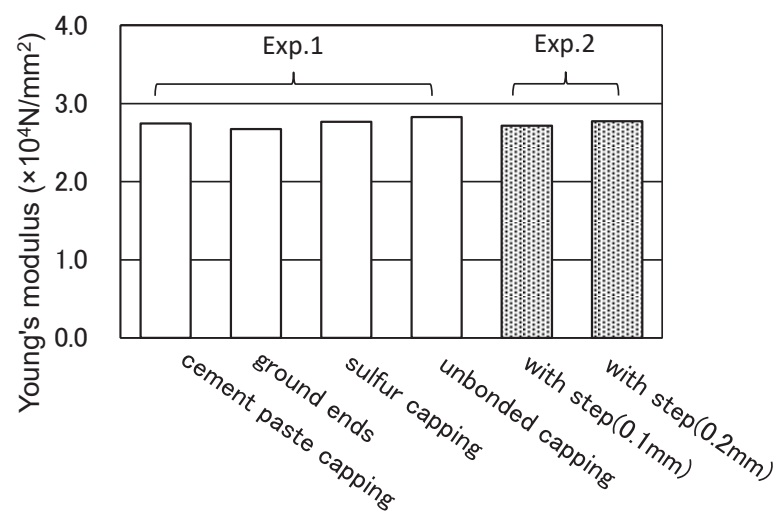

Fig. 13 Comparison of Young's modulus between specimens with various end surface treatment

ける，各測定位置におけるひずみを Fig.12(a)に，対面するひずみの 平均值を Fig.12(b)に示寸。なお, 図中には応力段階 $10 \mathrm{~N} / \mathrm{mm}^{2}$ 時点 の供試体上端面の圧力分布を示している。

同図(a)より，測定位置によりひずみのばらつきが生じており，標 準偏差（SD）は $37.2 \times 10^{-6}$ であった。この傾向は， $0.2 \mathrm{~mm}$ の段差 を設けた供試体においても同様であり，各測定位置のひずみの標準 偏差は $50.9 \times 10^{-6}$ と,ばらつきが大きくなることが確認された。ま た，同図(b)においては，対面する 2 本のひずみの平均值はほぼ同程 度となることが確認された。しかしながら，本研究で対象とした段 差付きの供試体は極端な条件のものである。許容し得る試験体の成 形精度とそれによって生じる供試体中央部のひずみ分布の程度に関 しては，別途の検討を要する。

Fig.13に, 各端面処理を施した供試体と段差を設けた供試体につ いて, 静弹性係数の平均值の比較を示す。なお, 供試体の平均縦ひ ずみ $50 \times 10^{-6}$ のときの応力は, 端面処理供試体は約 $1.3 \sim 1.6 \mathrm{~N} / \mathrm{mm}^{2}$, 上端面に段差を設けた供試体は約 $1.6 \sim 2.0 \mathrm{~N} / \mathrm{mm}^{2}$ であった。 


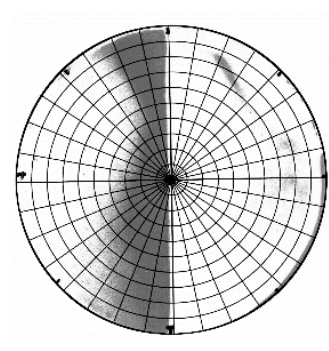

Fig. 14 Input data of stress distribution on meshed end face

Fig. 15 Strain measurement position in analysis

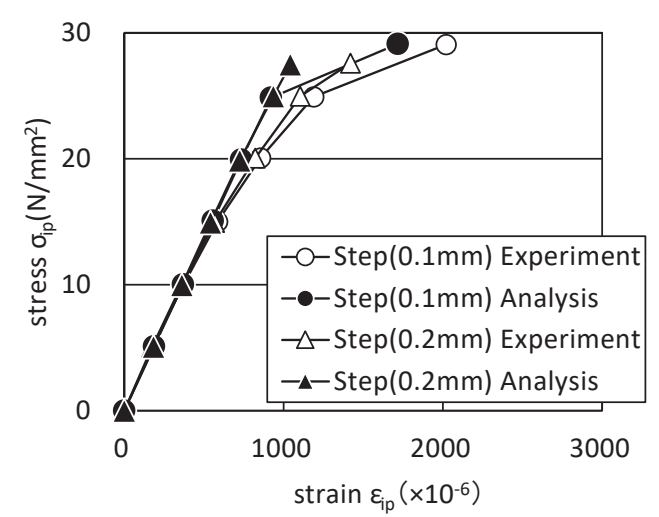

Fig. 16 Comparison between $\sigma_{i p}-\varepsilon_{i p}$ curves of analysis and experiment

\section{3 次元有限要素解析によるひずみおよび内部応力分布の検討}

\section{1 圧力分布の入力值}

Fig.14 に, 有限要素解析に用いた供試体端面のメッシュ分割の状 況と, 圧力測定フィルムより得られた圧力分布の一例を重政て示す。 メッシングでは, 円柱の半径方向に直径 $10 \mathrm{~mm}$ から $100 \mathrm{~mm}$ までの 同心円で 10 分割, 周方向を 32 分割し, 軸方向は 10 分割して解析 モデルを作成した。

\section{2 解析対象と構成モデル}

解析対象としたモデルは, 高さ $200 \mathrm{~mm}$, 直径 $100 \mathrm{~mm}$ の円柱体 とし, 実験に用いた供試体と同様に, 各解析モデルの端部には $0.1 \mathrm{~mm}$ および $0.2 \mathrm{~mm}$ の段差を設けた。

縦ひずみは Fig.15 に示すように, 図中の着色部分 (周の合計 8 箇 所）で測定した。また, 物性值として入力する静弾性係数およびポ アソン比は, 実験により得られた值 (静弾性係数 $2.7 \times 10^{4} \mathrm{~N} / \mathrm{mm}^{2}$, ポ アソン比 0.16）を用いた。

境界条件は, モデル底部を完全固定とし, モデル上面は圧力測定 フィルムの減摩効果による影響 17)を考慮し, 拘束条件を全方向自由 とした。また, 端面の各要素への入力荷重值は, 実測の圧力分布か ら得られた着色ピクセル（1ピクセル=約 $0.13 \mathrm{~mm} \times 0.13 \mathrm{~mm} ）$ の面 積から各要素 (メッシュ) の分担率を決定し, その総和が, 実験時 の載荷荷重と一致するように, 各要素の分担する荷重を決定した。

非線形解析を実施するにあたり, 解析プログラムには市販の Femap with NX Nastran v.9.1.0 Jを用いた。コンクリートは完全 弾塑性体とし, 降伏基準にはドラッカー・プラガーモデルを採用し た 18)。なお, 内部摩擦角は解析ソフトウェアの上限である 45 度と し, 粘着力は最大荷重時においても解析が安定的に終了寸る $7.5 \mathrm{~N} / \mathrm{mm}^{2}$ を設定し解析を実施した。このため, 本解析モデルでは,

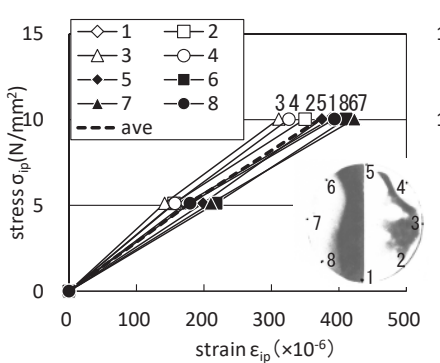

(a) Experiment

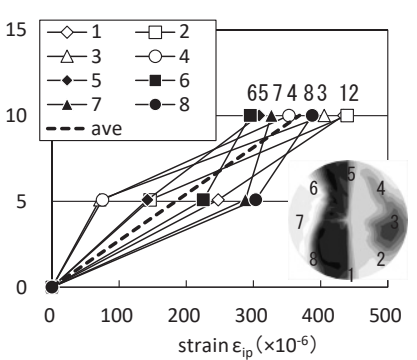

(b) Analysis
Fig. 17 Strain $\varepsilon_{i p}$ distribution at each stress stage up to $10 \mathrm{~N} / \mathrm{mm}^{2}$ (Step $0.1 \mathrm{~mm}$ )

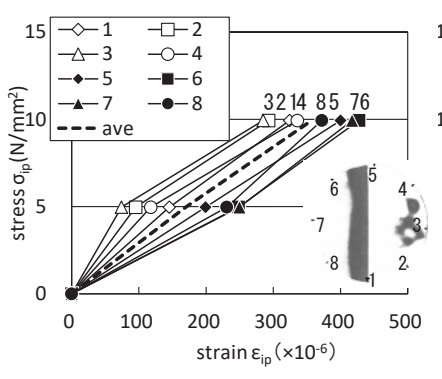

(a) Experiment

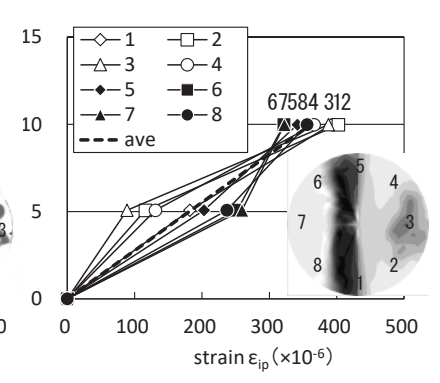

(b) Analysis
Fig. 18 Strain $\varepsilon_{i p}$ distribution at each stress stage up to $10 \mathrm{~N} / \mathrm{mm}^{2}$ (Step 0.2mm)

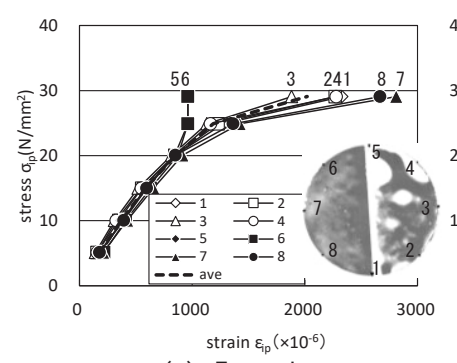

(a) Experiment

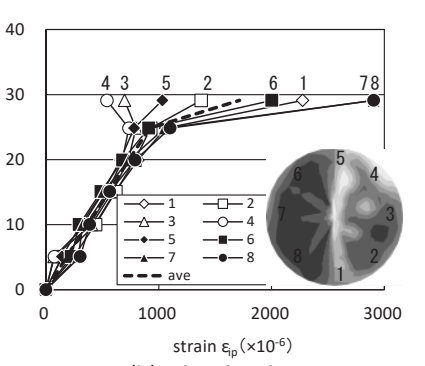

(b) Analysis
Fig. 19 Strain $\varepsilon_{i p}$ distribution at each stress stage up to $29.1 \mathrm{~N} / \mathrm{mm}^{2}$ (Step $0.1 \mathrm{~mm}$ )

1 軸圧縮強度が実験值と比較してやや大きい $36.2 \mathrm{~N} / \mathrm{mm}^{2}$ となって いる。

\section{3 解析結果および考察}

Fig.16 に, 実験および解析による応力 $\sigma_{i p}$ 一ひずみ $\varepsilon$ i $p$ 曲線の比 較を示す。同図より, 応力段階 $15 \mathrm{~N} / \mathrm{mm}^{2}$ 以降, 解析結果が実験結 果の $\sigma_{i p}-\varepsilon i p$ 曲線から分岐する傾向がみられるものの, 弾性域に おける応力ひずみ関係は概ね再現されていることが確認できる。

また, Fig.17 および Fig.18に, 各供試体の実験および解析結果 から得られた応力段階 $10 \mathrm{~N} / \mathrm{mm}^{2}$ に至るまでの, 各計測点の $\sigma_{i p}-$ $\varepsilon i p$ 曲線を示す。解析結果の $\sigma_{i p}-\varepsilon_{i p}$ 曲線は設けた段差の高さによ らず, 実験結果と比較して, 各ひずみの大小関係が異なることが確 認できる。これは, 応力段階 $10 \mathrm{~N} / \mathrm{mm}^{2}$ においては, 低圧用フィル ム（測定範囲 2.5-10MPa）を用いており，圧力が集中する上段側に おいては測定可能な範囲を超過し, 解析に入力寸る荷重を過小に評 価したためであると考えられる。

Fig.19に, 応力段階 $29.1 \mathrm{~N} / \mathrm{mm}^{2}$ (最大荷重時) までの, 各測定点 における応力ひずみ曲線を示す。同図(b)に示寸解析結果は, 実験結 果と同様に, ひずみ測定点 $1,7,8$ に縦ひずみの集中が確認された。 
これは, 最大荷重時の圧力分布の測定には中圧用フィルム（測定範 囲 10-50MPa）を用いたため, 先述した測定範囲を超過した領域が 少なく, 比較的精度良く解析モデルに荷重を入力できたためである と考えられる。

以上の結果から, 圧縮試験時の圧力分布を荷重条件として入力し た有限要素解析においても, ひずみ分布に及ぼす端部の圧力分布の 影響について, 部分的には再現されたと考えられるが, 精度の向上 にはより詳細な検討を要する。

\section{5. まとめ}

本研究では，コンクリートの圧縮試験における応力段階ごと供試 体上端面の圧力分布を実測し, これがひずみ分布および圧縮強度に 及ぼす影響に関して検討した。また, 載荷圧力の分布による供試体 のひずみ分布への影響について, 有限要素解析を用いた再現性に関 する検討も実施した。

以下に得られた知見を示す。

1）供試体の上端面の段差は, その值が $0.2 \mathrm{~mm}$ 程度になると圧縮強 度に影響を与える。

2）端面処理方法の違いにより, 既往の研究 10) と同様に載荷圧力の 相対的な分布状況 (着色模様) に違いが見られ, その違いは応力 レベルの低い段階（10N/mm² 程度）では顕著であったが，次第 に小さくなり，高い応力レベル（ $25 \mathrm{~N} / \mathrm{mm}^{2}$ 程度）では極めて小 さくなった。

3）上端面に段差を施した供試体の圧力分布に関して，初期応力段 階から供試体高さ中央部のひずみとの対応が見られなかったこ とから, 上端面の圧力分布と供試体内部の垂直応力分布は必ず しも一致しないと考えられる。

4）実測した圧力分布を入力荷重值とした有限要素解析を行ったと ころ，各ひずみの大小関係が正確には再現されなかったものの， 供試体上端面の圧力分布がひずみ分布に及ぼす影響は概ね再現 された。

\section{謝辞}

本研究の実施に際して, 水野英二先生（中部大学教授）および張 茈博氏 (三重大学大学院修了生) に, ご協力を頂きました。ここに, 記して謝意を表します。

\section{参考文献}

1) Tsujimoto, K., Kuroi, T., Matsumura, K., Suzuki, K.: Effect of Unbonded Capping System on Compressive Strength of Concrete, Proceedings of the Japan Concrete Institute, Vol. 33, No. 1, pp.377382, 2011.7 (in Japanese)

辻本一志, 黒井登起雄, 松村仁夫, 鈴木一雄：コンクリートの圧縮強度 に及ぼすアンボンドキャッピングの適用要因に関する基礎的研究：コ ンクリート工学年次論文集, Vol. 33, No. 1, pp. 377-382, 2011. 7

2) Tsujimoto, K., Kuroi, T., Matsumura, K., Suzuki, K.: Influcence of height-diameter ratio exerted on the compressive strength in a Unbond-capping method, Vol. 34, No. 1, pp. 328-333, 2012. 7 (in Japanese)

辻本一志, 黒井登起雄, 松村仁夫, 鈴木一雄 : アンボンドキャッピング 試験におけるコンクリートの圧縮強度に及ぼす供試体高さの影響，コ ンクリート工学年次論文集, Vol. 34, No. 1, pp. 328-333, 2012. 7

3) Kasai, Y: The Concrete Handbook, Gijutsu Syoin, pp. 407-412, 1998. 6 (in Japanese)
笠井芳夫：コンクリート総覧，技術書院, pp. 407-412, 1998. 6

4) Noguchi, T. and Tomosawa, F.: Effect of Preparation of Specimen Ends on Measured Compressive Strangth of High Strength Concrete, Journal of Structural and Construction Engineering (Transactions of AIJ), No. 475, pp. 1-7, 1995.9 (in Japanese)

野口貴文, 友澤史紀：高強度コンクリートの圧縮強度試験結果に及ぼす 供試体の上面処理方法の影響, 日本建築学会構造系論文集, 第 475 号, pp. 1-7, 1995. 9

5) Okada, K. and Muguruma, H.: Concrete Engineering Handbook, Asakura Syoten, p. 379, 1981. 11 (in Japanese)

岡田清，六車 熙コンクリート工学ハンドブック，朝倉書店, p. 379, 1981. 11

6) Suzuki, S., Koyama, Y., Jinnai, H., Hayakawa, M.: Basic Research on Influence of Loading Speed in the Compressive Strength Test on Results of Compressive Strength and Deformation Performance of Concrete, Journal of Structural and Construction Engineering (Transactions of AIJ), Vol. 74, No. 636, pp. 201-207, 2009. 2 (in Japanese)

鈴木澄江，小山善行，陣内浩，早川光敬：圧縮強度試験における荷重速 度がコンクリートの圧縮強度と変形性状に及ぼす影響に関する基礎的 研究，日本建築学会構造系論文集，第 74 巻，第 636 号, pp. 201-207, 2009. 2

7) Suzuki, S., Koyama, Y., Hayakawa, M, Jinnai, H..: Basic Research on Influence of Loading Speed in the Compressive Strength Test on Results of Compressive Strength and Deformation Performance Concrete (Part 2 Deformation Performance), Summaries of Technical Papers of Annual Meeting, Architectural Institute of Japan, A-1, pp. 919-920, 2009. 7

鈴木澄江，小山善行，早川光敬，陣内浩：圧縮強度試験における荷重速 度と強度レベルがコンクリート強度・変形性状に及ぼす影響 (その 2 強 度性状），日本建築学会大会学術講演梗概集, A-1, pp .919-920, 2009. 7

8) Matsumura, K. and Kuroi, T.: How to Handle Pressure Measurement Film in Pressure Analysis of Concrete, Proceedings of the JUSS Congress on Cement and Concrete, Vol. 39, pp. 27-32, 2012. 10 (in Japanese)

松村仁夫，黒井登起雄：コンクリートの圧力解析における圧力測定フィ ルムの取り扱い方, セメント・コンクリート研究討論会論文報告集, Vol. 39, pp. 27-32, 2012. 10

9) Matsumura, K. and Kuroi, T.: Method of Image Processing of Pressure Measurement Film in Pressure Analysis of Concrete, Proceedings of the Japan Concrete Institute, Vol. 35, No. 1, pp. 397402, 2013. 7 (in Japanese)

松村仁夫，黒井登起雄：コンクリートの圧力解析における圧力測定フィ ルムの画像処理方法, コンクリート工学年次論文集, Vol. 35 , No. 1, pp. 397-402, 2013. 7

10) Matsumura, K. and Kuroi, T.: Influence of Surface Finish Method on Compressive Strength of Concrete Specimen, Cement Science and Concrete Technology, Vol. 64, No. 1, pp. 169-176, 2010. 3 (in Japanese) 松村仁夫, 黒井登起雄：供試体の表面仕上げ方法がコンクリートの圧縮 強度に及ぼす影響, セメント・コンクリート論文集 64(1), pp. 169-176, 2010. 3

11) Matsumura, K. and Kuroi, T.: A Study on Relationship between Compressive Strength Level of Concrete and Surface Finish of Specimen, Proceedings of the JUSS Congress on Cement and Concrete, Vol. 38, pp. 31-36, 2011. 11 (in Japanese)

松村仁夫, 黒井登起雄：コンクリートの圧縮強度レベルと供試体表面仕 上げとの関係の一考察, Vol. 38, pp. 31-36, 2011. 11

12) Kuroi, T., et al.: Application limit of Unbond Capping in the Compressive Strength Test of Concrete, Proceedings of the JUSS Congress on Cement and Concrete, Vol. 36, pp. 29-34, 2009. 10 (in Japanese)

黒井登起雄, 宮澤伸吾, 松村仁夫, 辻本一志, 鈴木一雄：コンクリート の圧縮強度試験におけるアンボンドキャッピングの適用限界, セメン ト・コンクリート研究討論会論文報告集. Vol. 36, pp. 29-34, 2009. 10

13) Matsumura, K. and Kuroi, T.: Influence of Planar Characteristics of Loading Surface on Compressive Strength, Proceedings of the JUSS 
Congress on Cement and Concrete, Vol. 37, pp. 5-10, 2010. 11 (in Japanese)

松村仁夫, 黒井登起雄: 圧縮強度に及ぼす載荷面の平面特性の影響, セ メント・コンクリート研究討論会論文報告集, Vol. 36, pp. 5-10, 2010. 11

14) Irie, K., Kuroi, T. and Matsumura, K.: Influence of Height of Specimen on Compressive Strength of High-Strength Concrete, Proceedings of the Japan Concrete Institute, Vol. 30, No. 1, pp. 381386, 2008. 7 (in Japanese)

入江一次, 黒井登起雄, 松村仁夫: 高強度コンクリートの供試体端面の 圧力分布と円周方向ひずみに及ぼす高さの影響，コンクリート工学年 次論文集, Vol. 30, No. 1, pp. 381-386, 2008. 7

15) Kuroi, T.: Influence of End Friction on Compressive Strength and Pressure Distribution of Concrete, Proceedings of the JUSS Congress on Cement and Concrete, Vol. 40, pp. 39-44, 2013. 11 (in Japanese) 黒井登起雄：コンクリートの圧縮強度および圧力分布に及ぼす端面摩 擦の影響, セメント・コンクリート研究討論会論文報告集. Vol. 40, pp. 39-44, 2013. 11
16) Zhang, Z., Mshima, N. and Hatanaka, S.: Stress Distribution on Top Surface of Concrete Specimen under Compressive Loads with Various Top Surface Conditions, Proceedings of Tokai Chapter Architectural Reserch Meeting, Vol. 55, pp. 5-8, 2017. 2 (in Japanese)

チョウシハク，三島直生，畑中重光：一軸圧縮を受けるコンクリート供 試体上端面の応力分布に及ぼす供試体の端面処理方法の影響, 日本建 築学会東海支部研究報告集, Vol. 55, pp. 5-8, 2017. 2

17) Kosaka, Y., Tanikawa, Y., Ota, F.; On the Stress Distribution of Compressive Specimen End Face with Various Antifriction Materials, Proceedings of the Japan Concrete Institute, Vol. 2, pp. 121-124, 1980. 5 (in Japanese)

小阪義夫, 谷川恭雄, 太田福男: 各種の減摩材を用いた場合の圧縮供試 体端面の応力分布について, 第 2 回コンクリート工学年次講演会講演論 文集(1980), pp. 121-124, 1980.5

18) W.F.Chen: Plasticity in Reinforced Concrete, Maruzen, pp. 217-254, 1985. 7 (in Japanese)

WF.Chen：コンクリート構造物の塑性解析, 丸善, pp. 217-254, 1985. 7 


\title{
COMPRESSIVE PRESSURE DISTRIBUTION ON END FACE OF CONCRETE SPECIMENS AND ITS INFLUENCE ON MEASURED STRAIN DISTRIBUTION
}

\author{
Ryosuke FUJIKI*1, Shigemitsu HATANAKA*2 and Naoki MISHIMA*3 \\ ${ }^{* 1}$ Grad. Student, Div. of Arch., Graduate School of Eng., Mie Univ \\ *2 Prof., Div. of Arch., Graduate School of Eng., Mie Univ., Dr.Eng. \\ ${ }^{* 3}$ Assoc. Prof., Div. of Arch., Graduate School of Eng., Mie Univ., Dr.Eng.
}

The smoothness of the end surfaces of a concrete specimen is an important factor influencing the result of the compressive strength test, and there is a possibility that the apparent compressive strength changes greatly due to the smoothness of the end surfaces. Therefore, it is important to grasp stress distribution on the loading surfaces during compressive tests.

Measurement of pressure distribution by pressure measuring films is performed by the color forming layer and the color developing layer in between the pressed part of the specimen and a loading plate. Color development is carried out by microcapsules of color forming layer when they are broken by the applied pressure, resulting in a chemical reaction in which a color former therein is adsorbed to the color developing layer. The film is considered guite useful to investigate and analyze the pressure and internal strains distribution in a hardened concrete.

In this study, pressure distribution on the upper end surface at various stages of loading of normal strength concrete and longitudinal strain of the middle height of the specimen were measured by using the pressure measurement films and strain gauges, respectively. Experiments were carried out in two series. In Exp.1, various end face treatment methods were applied to the upper part of a specimen, and in Exp.2, a step was formed on the upper end face of the specimen. We examined the influence of these experimental factors on the compressive strength and strain.

In addition, the reproducibility of the strain test results of the specimen by FEM (Finite Element Method) analysis using measured pressure distribution data was also examined.

As for various end surface treatments, difference in pressure distribution was clearly observed according to the difference in the end surface treatment method, but it hardly affected the averaged strains of opposite side of a specimen.

As for the specimens with the step gap on the upper end surface, it was found that the compressive strength was not greatly affected if the gap of step was within $0.1 \mathrm{~mm}$, but was remarkably decreased when the gap exceeded 0.2 $\mathrm{mm}$. There was no correlation between pressure distribution and strain distribution at the beginning of loading (stress stage of $5 \mathrm{~N} / \mathrm{mm}^{2}$ ). It is considered that the loading plate became oblique due to the step gap on the upper end surface, and the pressure applied to the specimen propagated diagonally.

The main results in this paper are as follows:

1) Although there are differences in loading pressure distribution due to differences in end face treatment methods, the average values and of the opposite side strains Young's moduli are guile similar regardless the treatment methods.

2) By using the average value of the two opposite side strains, the influence of the step on the upper end face on the Young's modulus can be greatly reduced.

3) In the FEM analysis using the measured pressure distribution, the influence of the pressure distribution on the upper end face of the specimen was largely reproduced, in the strain distribution. 